Pamiętnik Literacki 2017, 4, s. 119-131
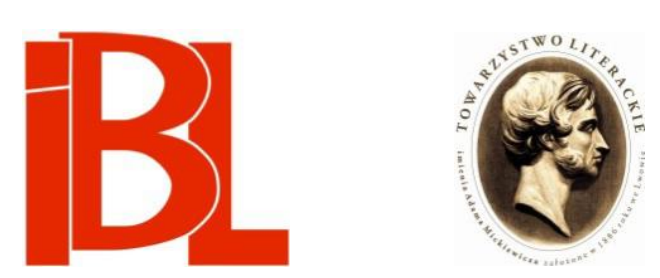

\title{
Reportaż literacki wobec literatury. Korzenie i teorie
}

\author{
Edyta Żyrek-Horodyska
}




\section{REPORTAŻ LITERACKI WOBEC LITERATURY KORZENIE I TEORIE}

Niniejszy artykuł stanowi próbę spojrzenia na współczesny reportaż literacki w kontekście wyraźnie dostrzegalnego dziś jego zwrotu w kierunku twórczości artystycznej. Przyznanie w 2015 roku białoruskiej dziennikarce Swietłanie Aleksijewicz literackiej Nagrody Nobla pokazało, iż granice między reportażem a literatura nie sa szczelne $^{1}$. Badacze już od dawna sygnalizują, że rozwój reportażu łączy się z kryzysem powieści ${ }^{2}$ oraz z dynamicznymi przemianami społeczeństwa informacyjnego. Związki reportażu literackiego i literatury mają zatem charakter wielowymiarowy i kształtują się pod wpływem rozmaitych czynników, które wynikają z przemian zarówno w obrębie gatunków prasowych, jak i form artystycznych.

Celem przedstawionych tu analiz jest wykazanie, iż otwarcie się reportażu na literaturę może być rozpatrywane $z$ kilku perspektyw. $Z$ jednej strony, interesujące wydaje się zbadanie literackich korzeni tego gatunku, który - choć ex definitione odrzuca fikcję i opiera się na przeświadczeniu o referencjalności języka - kształtował się przecież w wieku XIX przede wszystkim pod piórem najwybitniejszych pisarzy tamtego okresu, często wprowadzających do swoich tekstów elementy literackie. Warto zatem zastanowić się, jak ten fakt mógł wpłynąć na poetykę gatunku, który do dzisiaj nie doczekał się spójnej definicji. Ponadto na związki reportażu literackiego $z$ literaturą da się spojrzeć przez pryzmat najważniejszych teorii, które w XX stuleciu oddziałały na sposób myślenia o tym gatunku. Melchior Wańkowicz, Ryszard Kapuściński czy Hanna Krall wielokrotnie w swych wypowiedziach dotykali owej kwestii. Co ciekawe, podczas gdy pierwsi teoretycy, pisujący jeszcze w wie$\mathrm{ku} \mathrm{XX}$, dążyli do wskazania precyzyjnych granic między obiema formami piśmiennictwa, dzisiejsi reporterzy często te granice przekraczają. Intertekstualne nawiązania do dzieł literackich, pojawiające się w tekstach takich autorów, jak Mariusz Szczygieł, Mariusz Wilk czy Krystyna Kurczab-Redlich, dowodza, jak silnie dziennikarstwo czerpie $z$ technik narracyjnych i rezerwuaru środków artystycznych wypracowanych przez literaturę piękną.

Hayden White w szkicu Realizm figuralny $w$ literaturze świadectwa zwraca uwagę na dwie istotne kwestie, mające wpływ na współczesne rozumienie zawiłości i pozornie tylko oksymoronicznego (przynajmniej w swej nazwie) charakteru repor-

Zob. M. H o r o d e c ka, Słowo wstępne. „Jednak Książki” 5 (2016), s. 9.

Zob. M. C z e r miń s k a, Badania nad proza niefikcjonalna-sukcesy, pułapki, osobliwości. W zb.: Wiedza o literaturze i edukacja. Księga referatów Zjazdu Polonistów, Warszawa 1995. Red. T. M ichałowska, Z. Goliński, Z. J a rosiński. Warszawa 1996, s. 436. 
tażu literackiego. Na pytanie, w jaki sposób pogodzić w utworze niefikcjonalnym pierwiastek literacki $z$ werystycznym spojrzeniem na opisywaną rzeczywistość, White odpowiada, że każda historia jest głównie wytworem słownym, efektem poszczególnego użycia języka. Badacz podkreśla, iż nawet w tekście naukowym, a zwłaszcza w pracach historyków, prezentowana opowieść bywa kształtowana na wzór narracji literackich. Autorzy nie stronią od metafor, ich teksty zaś - w zależności od tematu - maja cechy romansowe, komediowe czy satyryczne ${ }^{3}$. White zwraca uwagę, że dane statystyczne oraz daty są tak naprawdę jedynie składowymi opowiadanych historii. Każdy z piszacych, dysponując tym samym zestawem informacji, fabularyzuje je w sobie właściwy sposób, nawet jeśli w swych ustaleniach kieruje się wyłącznie zasadami etyki naukowej. Osobami, które nadają znaczenie faktom, sa przede wszystkim autor oraz czytelnicy.

Można odnieść wrażenie, iż wiele uwag zanotowanych przez White’a oświetla zawiłości teoretyczne narosłe wokół reportażu literackiego. Takie tomy, jak Strategia antylop Jeana Hatzfelda czy Wojna nie ma $w$ sobie nic $z$ kobiety Aleksijewicz, w zamyśle twórców miały być właśnie dziennikarskim zbiorem świadectw ludzi, którym przyszło zmierzyć się z doświadczeniami wojny. Autorzy skonstruowali swe książki w dużej mierze $z$ przytaczanych $\mathrm{w}$ mowie niezależnej wypowiedzi osób ocalonych. Wielokrotnie deklarowali, iż taki sposób prowadzenia narracji pozwala uniknąć przefiltrowywania historii przez własną wrażliwość. Oddanie głosu bohaterom jest według Hatzfelda i Aleksijewicz próbą stworzenia reportażu literackiego dążącego do obiektywizmu. O pozorności i utopijności tego projektu bardzo szybko przekonał się autor Strategii antylop. Przytaczając w mowie niezależnej wypowiedzi Rwandyjczyków, nie uciekł przecież choćby od kwestii tłumaczenia, czyli przekładania cudzych doświadczeń na własny język. Równie problematyczne okazało się także zamienienie słowa mówionego na tekst pisany ${ }^{4}$.

Bycie „pomiędzy”, którego doświadczyli Hatzfeld i Aleksijewicz, jest - jak się zdaje - immanentnym składnikiem pracy reportera. Zdaniem Małgorzaty Czermińskiej, reportaż literacki, choć należy do gatunków dziennikarskich, często wykracza swą formą poza publicystykę ${ }^{5}$. W książce Autobiograficzny trójkat: świadectwo, wyznanie i wyzwanie badaczka zwraca uwagę na dostrzegalne dziś zacieranie się granic gatunków i na ich swoistą otwartość. Reportaż konkuruje $z$ takimi formami, jak biografia czy opis podróży, a nawet - w czym doszukiwać się można jego związków z twórczością artystyczną - oddziałuje na współczesną powieść, przyczyniając się do rozwoju tzw. powieści reportażowej ${ }^{6}$. O ile w połowie XIX wieku to literatura, szczególnie zaś - jak podkreśla Kazimierz Wolny-Zmorzyński - nowela wpływała na kształt reportażu ${ }^{7}$, o tyle dzisiaj reportaż z równą intensywnością oddziałuje na

3 H. Whit e, Realizm figuralny $w$ literaturze świadectwa. W: Proza historyczna. Red. E. D o m a ńs ka. Kraków 2009, s. 211 (przeł. E. Domańs ka).

Zob. Nie czuję strachu. Z J. Hatzfeldem rozmawia E. Win n i c k a. „Polityka” 2010, nr 48.

Czermińs ka, op. cit., s. 444.

M. Czermińska, Autobiograficzny trójkąt: świadectwo, wyznanie i wyzwanie. Kraków 2004, s. 249.

$7 \quad$ K. W olny - Z m o r zy ń s ki, Reportaż - jak go napisać? Poradnik dla słuchaczy studiów dziennikarskich. Warszawa 2004. 
literaturę. Jako przykład wskazać można słynną powieść $Z$ zimna krwia Trumana Capote'a, inspirowaną autentycznymi wydarzeniami.

\section{W poszukiwaniu definicji}

Reportaż literacki jest jednym z najtrudniej definiowalnych współcześnie gatunków dziennikarskich. Ze względu na swój hybrydyczny, proteuszowy charakter i kłopotliwe umiejscowienie między literaturą a publicystyką pozostaje wciąż formą wymykająca się precyzyjnym ustaleniom genologicznym. Nie oznacza to wszakże, jakoby starania definicyjne medioznawców i literaturoznawców zainteresowanych poetyką tego gatunku ustawały. W roku 2016 ukazał się piąty numer gdańskiego czasopisma „Jednak Książki”, zatytułowany Reportaż literacki. Pogranicza. Zebrane w nim wypowiedzi badaczy dowodzą ogromnego zainteresowania, jakim cieszy się dziś już nie tylko reportaż prasowy (co trafnie przewidziała kilka lat temu Czermińska), ale też jego szczególna odmiana, jaką jest reportaż literacki.

$\mathrm{W}$ jednym $\mathrm{z}$ artykułów zamieszczonych we wspomnianym czasopiśmie Joanna Jeziorska-Haładyj pokazuje, jak w XX stuleciu na łamach „Rocznika Literackiego” kształtował się stosunek redaktorów do literackości reportażu ${ }^{8}$. Badaczka stawia tezę, iż „formułowane dzisiaj argumenty na rzecz lub przeciwko literackości reportażu są echem dyskusji sprzed lat”, pokazując, jak istotne znaczenie temat ten miał dla piszących już w połowie XX wieku. Medioznawcy i teoretycy gatunków nie pozostają zgodni co do sposobu rozumienia przymiotnika „literacki”, skoro - w świadomości potocznej - budulcem tekstów dziennikarskich jest fakt, artystycznych zaś fikcja. Na stanowisku radykalnym staje Maciej Siembieda, określający literackość mianem „choroby reportażu”. Autor zauważa, iż nadmiar atrakcyjnych porównań i opisów, stosowanych przez twórców non-fiction, przyczynia się do powstawania tekstów grafomańskich, dalekich od postulowanych standardów dziennikarskiego rzemiosła ${ }^{10}$. Równie nieprecyzyjna może wydać się definicja zaproponowana przez Marię Gołaszewską, która wiąże reportażową literackość z fikcyjnością: „reportaż "czysty" to taki, który nie zawiera fikcji literackiej, "literacki" zaś - to nasycony elementami owej fikcji" ${ }^{11}$.

Paweł Zajas w książce Jak świat prawdziwy stat się bajką. O literaturze niefikcjonalnej słusznie przestrzega, że wszelkie próby precyzyjnego wyznaczenia granic między literaturą piękną a formami niefikcjonalnymi muszą skończyć się niepowodzeniem. Nacisk położony powinien zostać bowiem nie na cechy morfologiczne, lecz przede wszystkim na recepcję ${ }^{12}$. Poszanowanie paktu referencjalnego staje się według badacza jednym $z$ najważniejszych kryteriów definiowania gatunków prasowych. W świetle tych ustaleń warto przyjrzeć się argumentom podnoszonym przez Artura Domosławskiego w głośnej książce Kapuściński non-fiction. Pozycja ta - jak

J. J e zi o r s k a - H a ł a d y j, O granicach reportażu na łamach „Rocznika Literackiego” (1932-1984). „Jednak Książki” 5 (2016).

Ibidem, s. 22.

M. Si e m bi ed a, Reportaż po polsku. Poznań 2003, s. 68.

M. Goła szew s k a, Estetyka rzeczywistości. Warszawa 1984, s. 192.

P. Zaj a s, Jak świat prawdziwy stał się bajka. O literaturze niefikcjonalnej. Poznań 2011, s. 13. 
wspomina Zajas - wywołała w Polsce żywą dyskusję nad sposobami definiowania granic między literackością a dokumentarnością tekstu reportażowego. Domosławski zarzucał autorowi Cesarza np. niedokładne relacjonowanie faktów, a także wymyślanie epizodów, które pod względem estetycznym doskonale wkomponowywały się w dyskurs o Afryce, ale nie miały żadnego źródła w rzeczywistości ${ }^{13}$.

Zgoła odmiennie problem ten postrzega Edward Balcerzan, wyróżniający dwa podstawowe typy reportażu: dziennikarski i literacki. Badacz polemizuje z potocznym stwierdzeniem, że „reportaż literacki jest po prostu "ładniej« napisany, silniej nasycony figurami i tropami" ${ }^{14}$. Nie o styl bowiem chodzi, lecz przede wszystkim o uwagę, jaką obu rodzajom tekstów poświęca czytelnik:

Głos rozstrzygający ma w tym względzie projekt czytelnika. Adresat upatrzony przez autora jest tu [...] osobowością ukształtowaną przez tradycję literacką. Bez literackich doświadczeń - całość nie może się ukonstytuować w pełni swoich znaczeń. Rzeczywistość utrwaloną w tekście trzeba zorientować wobec wizji świata kreowanych w powieści, dramacie, liryce. Takie warunki dyktuje - między innymi Kapuścińskiego Busz po polsku ${ }^{15}$.

Literaturoznawca słusznie przestrzega, by literackości w reportażu nie odczytywać w kategorii ornamentów stylistycznych wzbogacających tekst. Podobnie jak w twórczości artystycznej, także tutaj powinny one stać się bowiem raczej nośnikami sensów. Tym, co łączy nastawienie dziennikarskie i literackie motywacje piszącego, jest chęć spotkania $z$ Innym, zbliżenia się do niego oraz przekazania jego historii czytelnikowi:

Reporter-dziennikarz i reporter-artysta zachowują się podobnie, gdyż i jeden, i drugi przenika do strefy INNOŚCI, znanej pobieżnie - niekiedy fałszywie - lub zgoła nieznanej ogółowi, do którego sam należy ${ }^{16}$.

Wydaje się, że podstawowa różnica między poznawaniem Innego przez literata i dziennikarza wiąże się z możliwością (bądź jej brakiem) wykorzystywania w tym procesie wyobraźni. Podczas gdy obaj autorzy stawiają sobie za cel przekazanie czytelnikowi informacji o „swiatach zamkniętych, oddalonych, egzotycznych”" pisarz dysponuje większą swobodą twórczą i korzystać może ze zdecydowanie szerszego zasobu środków wyrazu.

Andrzej Kaliszewski, analizując związki dziennikarstwa i twórczości artystycznej, dostrzega występujący we współczesnym dyskursie naukowym element wartościowania. Badacz wspomina o widocznym dzisiaj „podnoszeniu reportażu do rangi literatury" ${ }^{18}$. Już od XIX stulecia publicystykę, w którą angażowali się wtedy najwybitniejsi literaci, tacy jak Victor Hugo, Adam Mickiewicz czy Samuel Taylor Coleridge, uznawano za gorszą siostrę literatury. Pisujących do prasy autorów piętnowano za kierującą nimi chęć zysków i za to, że zaprzedali swoją artystyczną muzę. Współcześnie, jak pisze Wolny-Zmorzyński, owo przeświadczenie, każące

A. D o mo sła w s ki, Kapuściński non-fiction. Wyd. 2, uzup. Warszawa 2017, s. 525-554.

E. B alc e rza n, Literackość. Modele, gradacje, eksperymenty. Toruń 2013, s. 181.

Ibidem.

Ibidem, s. 180.

Ibidem.

A. Ka li sz ew s ki, Od socrealizmu do metafizyki - poezja Ryszarda Kapuścińskiego. W: Wieczna gra. Artykuty i szkice. Kraków 2009, s. 39. 
oceniać niżej teksty dziennikarskie od dzieł literackich, także daje się zaobserwować - nawet w dyskursie naukowym:

Dla historyków literatury „reportaż” nie zasługuje na miano gatunku literackiego. Uważany jest za gatunek typowo dziennikarski [...]. Jeśli już, to traktowany jest jako gatunek paraliteracki, rozpięty między literaturą a dziennikarstwem ${ }^{19}$.

Amerykański badacz Norman Sims w rozprawach poświęconych dziennikarstwu literackiemu ${ }^{20}$ celowo - jak twierdzi - unika precyzyjnego zdefiniowania pojęcia literary journalism. Zdaniem badacza, w trakcie przygotowywania tekstów dziennikarze mniej lub bardziej świadomie korzystają z rozwiązań fabularnych, jakie znają z lektury dzieł literackich. Potwierdzenia słów Simsa szukać należy chociażby w wypowiedziach Szczygła, który w wywiadzie udzielonym Agnieszce Wójcińskiej deklarował głębokie przywiązanie do inspirującej go jako autora non-fiction twórczości Kurta Vonneguta:

dla mnie inspiracją największą jest jeden pisarz. Mój ulubiony, choć nie umiałbym streścić żadnej jego powieści, nawet trudno mi powiedzieć, o czym te powieści są. Ale kiedy w chwilach rozpaczy twórczej biorę do ręki jego książkę, wyłapuję poszczególne zdania i akapity, przeczytam ze trzy, cztery i już mnie inspiruje swoim widzeniem świata ${ }^{21}$.

Ze związków między literaturą a dziennikarstwem zdają sobie sprawę sami piszący, którzy wielokrotnie w sposób otwarty zapewniają o przywiązaniu do określonych dzieł, twórców czy nurtów literackich. W przypadku reportażu literackiego dokumentarność i artyzm nie są traktowane jako kategorie przeciwstawne, lecz wzajemnie się uzupełniające. Wpływ na to ma z pewnością geneza gatunku, który już od początków swojego istnienia immanentnie łaczył się ze środowiskiem artystycznym.

\section{Korzenie}

„Bo reportaż jest tak stary jak mowa ludzka” - zapewniał w Karafce La Fontaine’a Wańkowicz, przestrzegając jednocześnie literatów, by z szacunkiem odnosili się do gatunku, „z którego lędźwi się poczęli”22. Twórca Ziela na kraterze nie ma tutaj jeszcze na myśli reportażu w znaczeniu zbliżonym do współczesnego, lecz raczej każdy przekaz, którego autor donosił (od łac. reportare) odbiorcy o istotnych $z$ jego punktu widzenia wydarzeniach. Prereportaże - zdaniem Wańkowicza - pisali już Homer, opowiadający o pojedynku Achillesa z Hektorem, Tacyt, Jan Długosz czy Herodot ${ }^{23}$. Dziennikarskie zamiłowania tego ostatniego dostrzegł także Kapuściński, który doszukał się w Dziejach cech charakterystycznych dla uprawianego przez siebie gatunku ${ }^{24}$.

K. Wolny-Zmor zyń ski, wstęp w: Mistrzowie reportażu. Antologia. Oprac. ... Rzeszów 2001, s. 7.

Zob. np. N. Si m s, True Stories: A Century of Literary Journalism. Foreword T. C o n o v e r. Evanston 2007.

Cyt. za: A. Wój cińs s a, Reporterzy bez fikcji. Rozmowy z polskimi reporterami. Wołowiec 2011, s. 175.

M. W a ń k o w i c z, Karafka La Fontaine'a. T. 1. Wstęp A. G r o n c zew s ki. Warszawa 2010, s. 39.

Zob. ibidem.

R. Ka puściń s ki, Podróże z Herodotem. Kraków 2004. 
Wykrystalizowanie się reportażu prasowego poprzedził rozwój form literackich bądź użytkowych, których autorzy, będący świadkami interesujących wydarzeń, stawiali sobie za cel utrwalenie ich na kartach relacji z podróży. Przykładem pierwszych tekstów dokumentarnych o takim charakterze jest grecka periegeza, definiowana jako rodzaj naukowego opisu krain czy regionów ${ }^{25}$. Swoistym „dokumentem drogi” był także popularny staropolski itinerariusz. Jak zauważa Czesław Niedzielski, przed pojawieniem się reportażu prasowego to właśnie inspirowane bliskimi bądź dalekimi wojażami opisy wychodzące spod piór literatów miały zarówno dokumentować to, co zobaczone, jak i wyrażać „woluntarny i emotywny stosunek poznającej jednostki do rzeczywistości nieznanej, nowej" ${ }^{26}$. Sytuacja zmieniła się w epoce oświecenia, gdy funkcję dokumentarną zaczęto przyznawać również powieści (by wspomnieć tylko Pana Podstolego Ignacego Krasickiego) ${ }^{27}$, poruszającej aktualne tematy, dyskutowane paralelnie także na łamach ówczesnej prasy ${ }^{28}$.

Wiek XIX w sposób szczególny uprzywilejował formę listu z podróż ${ }^{29}$, który oprócz opisu wrażeń autora ukazywał też nierzadko obszerne tło polityczne, gospodarcze bądź kulturowe wydarzeń. Korespondencje te można uznać za swoisty pomost między prasą a literaturą, zwłaszcza gdy weźmie się pod uwagę fakt, iż pierwsze periodyki powstające w wieku XVI były właśnie w dużej mierze zbiorami rozmaitych listów, nowin ${ }^{30}$. Szkice, kartki i obrazki z podróży cieszyły się przez cały wiek XIX ogromną popularnością - by wspomnieć tylko Listy z podróży do Ameryki Henryka Sienkiewicza, Listy z Berlina Heinricha Heinego czy wysyłane przez Stendhala do brytyjskich czasopism korespondencje o literaturze i obyczajach francuskich. Redagowane przez autorów opisy podróży - jak nadmienia Jolanta Sztachelska szybko zwróciły uwagę ówczesnych tytułów prasowych. W wieku XIX „nie mógł się bez nich obejść żaden szanujący się tygodnik czy dziennik. Relacje te zazwyczaj mocno już odbiegały od pierwotnej postaci listu, stając się wielokształtną i wielostykową wypowiedzą o innych krajach" ${ }^{31}$.

Sztachelska w obszernym szkicu poświęconym genezie reportażu zauważa, że nawet w wieku XIX, gdy następowała powolna profesjonalizacja zawodu dziennikarskiego, poprzedzona rozwojem prasy masowej pierwszej generacji, trudno było mówić o reportażu we współczesnym rozumieniu tego słowa ${ }^{32}$. Niedzielski zaznacza, że w XIX-wiecznym zasobie słownikowym leksem „reportaż” w ogóle się nie poja-

Zob. J. S c h n ay d e r, Periegeza w literaturze greckiej. Powstanie i rozwój gatunku. Kraków 1946. Cz. Niedzielski, O teoretycznoliterackich tradycjach prozy dokumentarnej. Podróż, powieść, reportaż. Toruń 1966, s. 6.

Zob. ibidem, s. 11.

Znamienne, że w wieku XVIII, wraz z rozwojem sentymentalizmu, obok podróży awanturniczej, nastawionej na kolekcjonowanie przygód, pojawia się również podróż intymna, wewnętrzna, skoncentrowana wokół doświadczania i przeżywania.

Wspomnieć warto w tym miejscu o słynnej serii „Podróże” (redagowanej przez P. Hertza), w której wydane zostały reprezentatywne dzieła literatury podróżniczej.

Zob. J. S z t a c h e l s k a, Reportaż. Z historii gatunku w wieku XIX. „Białostockie Studia Literaturoznawcze" 4 (2013), s. 155.

J. Szta chelska, „Reporteryje” i reportaże. Dokumentarne tradycje polskiej prozy $w 2$ pot. XIX i na pocz. XX wieku. (Prus, Konopnicka, Dygasiński, Reymont). Białystok 1997, s. 53.

Ibidem. 
wia $^{33}$. W drugiej połowie XIX stulecia zatrudniani w redakcjach reporterzy traktowani byli jako dostarczyciele informacji i plotek zasłyszanych gdzieś na ulicy oraz jako współpracownicy redaktorów, cieszących się zdecydowanie większym poważaniem. Pod względem walorów artystycznych teksty te dalekie były od szczególnie cenionej wtedy literatury. Już wówczas kształtowały się jednak - jak pisze Sztachelska - pewne cechy morfologiczne, które decydowały o przynależności do powstającego gatunku. Znaczną część wypowiedzi prereportażowych charakteryzowały: odwoływanie się do motywu wędrówki, scalający historię narrator oraz wplatane $\mathrm{w}$ tekst liczne zapewnienia piszącego co do autentyczności relacjonowanych przez niego wydarzeń ${ }^{34}$. Co istotne, zapowiedzi tych tendencji pojawiały się także w ówczesnej literaturze, o czym może świadczyć już słynne sformułowanie Stendhala, który widział w powieści lustro przechadzające się po gościńcu.

Już od wieku XVIII zaczęły się formować pierwsze związki literatów i publicystów. Wspomina o tym Wańkowicz, słusznie podając przykład Daniela Defoe, który zasłynął zarówno dzięki swym powieściom, jak i dzięki tekstom o charakterze prereportażowym - przywołajmy chociażby szkic The Storm (Burza). Rozwijające się w oświeceniu czasopisma moralne, m.in. brytyjski „The Tatler” czy naśladujący go polski „Monitor”, także przyciagnęły do publicystyki najwybitniejsze pióra epoki. W Anglii wielu ówczesnych autorów, wśród których znalazł się Coleridge, zajmowało się przygotowywaniem sprawozdań $z$ obrad parlamentu. Momentem przełomowym dla formowania się związków między światem prasy a literatury były jednak dopiero lata dwudzieste i trzydzieste XIX stulecia, gdy w Stanach Zjednoczonych i w Europie rozwijać się zaczęła prasa masowa. Słynna francuska „La Presse”, redagowana przez Émile'a de Girardina, stała się wzorem do naśladowania dla założycieli innych europejskich gazet, które od tego momentu z jeszcze większą przychylnością spoglądać zaczęły na pozostających często bez trwałego zajęcia twórców literatury. Z prasą współpracowali tacy pisarze, jak Adam Mickiewicz, Józef Ignacy Kraszewski, Victor Hugo, Honoré de Balzac, Percy Bysshe Shelley czy Leigh Hunt. Niektórzy - np. Henryk Rzewuski - przyczynili się nawet do reformy rodzimego dziennikarstwa ${ }^{35}$.

Choć reportaż literacki w połowie XIX stulecia nie był jeszcze gatunkiem wyraźnie wyodrębnionym, wśród twórców zaczęły pojawiać się już pierwsze głosy sugerujące konieczność podjęcia szerszego namysłu nad nową formą piśmiennictwa. Jednym $z$ najważniejszych inicjatorów zasygnalizowanych tu przemian stał się francuski dziennikarz i publicysta Jules Vallès. Jak konstatują Guillaume Pinson i Marie-Ève Thérenty, był on prawdopodobnie pierwszym autorem, który świadomie, w ramach precyzyjnie opracowanego projektu, starał się włączać pierwiastki artystyczne i literackie do tekstów reportażowych ${ }^{36}$. W „La Rue” wystosował nawet postulat „po fałszywym życiu - życie prawdziwe” ${ }^{37}$, dając tym samym wyraz swemu

Cz. Ni e d zi els ki, Reportaż. Hasło w: Stownik literatury polskiej XIX wieku. Red. J. B a c h ó r z, A. Kowalczykowa. Wyd. 2. Wrocław 1994, s. 820.

34 Zob. Szta chels ka, Reportaż, s. 160-161.

35 Autor Pamiatek Soplicy założył własny tytuł prasowy pod nazwą „Dziennik Warszawski”, zatrudniając w nim regularnie opłacanych dziennikarzy. 
przekonaniu o konieczności dzielenia się z czytelnikiem przede wszystkim prawdziwymi doświadczeniami oraz informacjami. W czasie gdy tworzył Vallès, francuscy pisarze-dziennikarze zamieszczali w prasie głównie tworzone zza biurka felietony. Podróżując do nowych miejsc (co wiązało się z wielką XIX-wieczną ideą grand tour), spoglądali na nie najczęściej $z$ perspektywy flaneûra, skoncentrowanego bardziej na osobistym przeżyciu aniżeli na tym, co stanowi przedmiot oglądu.

Wielka Wystawa Światowa zorganizowana w 1851 roku w Londynie przyciagnęła uwagę wielu francuskich publicystów, którzy w obowiązującym wówczas wysoce subiektywnym, literackim tonie przedstawiali w prasie swe wrażenia $z$ pobytu $\mathrm{w}$ angielskiej stolicy. Vallès po powrocie $\mathrm{z}$ Londynu wystapił otwarcie przeciwko takiemu sposobowi pisania, wysuwając na pierwszy plan przemiany, jakie winny zajść w pracy reportera: „Należy zakupić notatnik, duży ołówek, aby notować fakty, oznaczać wydarzenia [...]"38. Notatnik i pióro mają odtąd służyć reporterowi do tego, by mógł on na bieżąco zapisywać szczegóły, które pozwolą mu stworzyć tekst opierający się przede wszystkim na chose vue - „rzeczy zobaczonej”.

Pinson i Thérenty twierdza, że londyńska wyprawa Vallèsa była pierwszym krokiem w konstruowaniu teorii europejskiego reportażu ${ }^{39}$. W obrębie gatunku stopniowo wyodrębnił się reportaż sportowy, literacki czy społeczny. W Polsce dopiero twórcy pozytywistyczni zaczęli z większą atencją przyglądać się pracy dziennikarskiej, mimo że romantycy nie przechodzili przecież obojętnie obok możliwości, jakie oferowała im ówczesna prasa. W drugiej połowie XIX stulecia pojawiali się już autorzy, którzy wyżej niż wytwory swej wyobraźni stawiali wydarzenia autentyczne. Hanna Natora-Macierewicz wskazuje postać Feliksa Fryzego, uznając go za jedną z najważniejszych postaci polskiego dziennikarstwa ${ }^{40}$. Charakteryzując jego dorobek artystyczny, badaczka posługuje się pojęciem reportażu. Redaktor „Kuriera Porannego" bodaj jako pierwszy w Polsce jawnie angażował się w precyzyjne oddzielenie od siebie literatury i dziennikarstwa. $Z$ przekonaniem deklarował: „byłem pierwszym w Warszawie czystej rasy dziennikarzem, i niczym więcej" ${ }^{41}$.

Podobnie jak Vallès we Francji, w Polsce Fryze także opublikował tekst o charakterze teoretycznym, który miał być dla współpracowników prasy zbiorem normatywizującym zasady uprawiania zawodu ${ }^{42}$. Choć w pisanych w 1899 roku Radach dla dziennikarzy nie znajdziemy jeszcze precyzyjnych wypowiedzi na temat reportażu, obszerne passusy tego tekstu świadczą o tym, że Fryze widział w polskiej prasie miejsce dla tego gatunku:

Naturalnie, skoro dziennik ma być zwierciadłem życia, więc wobec klęski powodzi będzie musiał być pełen opisów żywiołowej katastrofy, w czasie wyścigów musi im poświęcić sporo miejsca [...]. Niezwykła sprawa lub krzycząca zbrodnia musi uszczuplić miejsca innym działom ${ }^{43}$.

Cyt. jw., s. 10.

Ibidem.

H. Natora-Macierewicz, Amerykańskie wzory (Feliks Fryze). „Kwartalnik Historii Prasy Polskiej" 1991, nr 3/4.

Cyt. jw., s. 101-102.

F. Fry ze, Rady dla dziennikarzy. „Zeszyty Prasoznawcze” 1979, nr 3. (Pierwodruk w zb.: Księga jubileuszowa „Kuriera Porannego” 1877-1902. Red. F. Fryz e. Warszawa 1903).

Ibidem, s. 109. 
W ujęciu Fryzego reporter to autor, którego teksty opierają się przede wszystkim na własnym doświadczeniu. Jego celem i ambicja - inaczej niż u literata - jest zaprzestanie przygotowywania szkiców dziennikarskich niejako zza biurka. Najistotniejsze winno być skoncentrowanie się na rzeczywistości, wnikliwa obserwacja oraz szybkość w przekazywaniu informacji.

\section{Teorie}

Dynamiczny rozwój reportażu w wieku XX przyczynił się do powstania licznych wypowiedzi teoretycznych, które miały stanowić podwaliny dla ukształtowania się gatunku w pełni już samodzielnego i niezależnego od literatury. Ich autorzy w swych ustaleniach często jednak powracali do związków obu form twórczości i z mniejszą jak się zdaje - niż ich pozytywistyczni poprzednicy żarliwością nawoływali do całkowitego oddzielenia od siebie dziennikarstwa i literatury. Fakt ten nie pozostał bez wpływu na rozwój reportażu, który w wieku XX za sprawą takich mistrzów pióra, jak Wańkowicz, Kapuściński, Jerzy Lovell czy Krzysztof Kąkolewski, zaczął stopniowo uniezależniać się od prasy drukowanej. Reportaż, a zwłaszcza reportaż literacki, w XX stuleciu coraz częściej ukazuje się w formie książkowej, korzystając z rozwiązań wydawniczych zarezerwowanych do tego momentu głównie dla literatury. Równocześnie na łamach prasy zaczyna rozwijać się szkic reportażowy, charakteryzujący się jednowątkowościa i skrótowościa przekazu ${ }^{44}$.

Do związków literatury i reportażu w swej refleksji teoretycznej nierzadko powracał Wańkowicz na kartach Karafki La Fontaine'a. W rozdziale Poszerzenie konwencji reportażu autor podejmuje namysł m.in. nad występowaniem fikcji w formach dziennikarskich. Zauważa, że artyzm - właściwy twórcom dzieł literackich - to również niezbywalny element pracy reportażysty, którego celem nie jest szczegółowe opisywanie losów jednostek, lecz przekazanie ogólniejszej prawdy o ich życiu:

W pogoni za prawdą dosłowną musiałbym albo zajmować się losem każdego człowieka od początku do końca - na to by trzeba całych tomów, albo też wziąć z każdego życia moment najciekawszy. Ale wówczas byłaby to siekanina, kilkadziesiąt nie połączonych ze sobą wątków. Byłaby to prawda literalna, ale nie byłoby w tym prawdy generalnej $[\ldots]^{45}$.

Zdaniem Wańkowicza, dobry reportażysta potrafi połączyć w swym tekście artyzm przedstawienia $z$ siłą faktów. Nadmierne wykorzystywanie zabiegów literackich dziennikarz określa mianem „poślizgu na lodowisku beletrystyki” ${ }^{46}$, którego ofiara padają nawet najbardziej utalentowani autorzy.

Refleksja Wańkowicza nad związkami reportażu oraz literatury nie sprowadza się jednak wyłącznie do namysłu nad zagadnieniami prawdy i fikcji. Wiele uwagi

Jak zauważa K. W olny-Zmor zy ń s ki (Poetyka reportażu polskiego po 1989 roku. Zarys problematyki. W zb.: Reportaż a przemiany społeczne po 1989 roku. Red. ..., W. F u r m a n. KrakówRzeszów 2005, s. 26), współcześnie w mediach masowych gatunkiem szczególnie dynamicznie się rozwijającym jest feature: „Feature to po prostu odpowiedź na zapotrzebowanie chwili - szybki przekaz; orientowanie odbiorcy w tym, co się gdzieś niedaleko niego wydarzyło". 
autor Tworzywa poświęcił bowiem także samemu procesowi lektury, wspominając o „pasji czytelniczej” 47 , którą rozwijać w sobie winni wszyscy adepci dziennikarstwa. Wańkowicz zachęca do szerokiego spojrzenia zwłaszcza na rodzimą twórczość. „Lektura jest niezbędnym zwielokrotnieniem informacji oraz pisarskiej chłonności”48 - powiada, przestrzegając równocześnie przed ignorowaniem przez dziennikarzy tego, co dzieje się w literaturze:

Jestem reporterem i muszę powiedzieć w obronie swego pisarskiego gatunku, że reporter, który jest artysta, musi przerobić te wszystkie dyscypliny co i powieściopisarz, a nadto umieć się umykać własnemu żarłocznemu gatunkowi literackiemu, który mu grozi zniszczeniem. Jest to Niagara faktów, od których nie może się tak łatwo odgrodzić jak powieściopisarz ${ }^{49}$.

Oba tomy Karafki La Fontaine'a wypełnione sa tysiącami rozmaitych cytacji, zaczerpniętych w znacznej mierze $\mathrm{z}$ dzieł literackich. Autor zachęca nawet początkujących dziennikarzy do tworzenia własnych kartotek, gdzie znajdować się będą inspirowane literaturą bon moty. Wańkowicz wyraża głębokie przekonanie o ogromnej doniosłości cytatów w reportażu, które mają być nie tylko świadectwem erudycji piszącego, lecz przede wszystkim sposobem na najlepsze z możliwych przedstawienie zaistniałej sytuacji, niecodziennego wydarzenia:

O cytatach Emerson powiedział, że najbliższym autora dobrej sentencji jest ten, który ją pierwszy zacytuje. Ja zaś uważam, że najbliższym jest ten, który łącząc ją z innymi cytatami, wywołuje ich polaryzację, stającą się $\mathrm{z}$ kolei samoistną wartością ${ }^{50}$.

Dostrzegalne u Wańkowicza tak silne jeszcze zakorzenienie reportażu w literaturze odległe jest od ustaleń teoretycznych formułowanych przez Krall. Autorka ta, uznawana dziś przez młodych reporterów za jeden $z$ głównych dziennikarskich autorytetów ${ }^{51}$, wielokrotnie w swych wypowiedziach powracała do związków sztuki i dziennikarstwa. W odróżnieniu od twórcy Sztafety - w sposób jednoznaczny opowiedziała się po stronie prawdy dokumentarnej, odrzucając chociażby tak ważną dla niego wyobraźnię. Zdecydowanie częściej w swych wypowiedziach teoretycznych wskazywała na różnice między tymi dwiema sferami aktywności niż na łączące je podobieństwa:

Pisarz to ktoś wielki, kto ma ogromną odwagę, stwarza świat, zaludnia go. Są parowy, ulice, domy, topografia, rozpoznaje się miejsca i ludzi, jak u Faulknera. A ja nie stwarzam, ja mówię o świecie stworzonym przez kogoś innego ${ }^{52}$.

Zdecydowana większość wypowiedzi autorki Wrzenia świata dotyczących analizowanego zagadnienia koncentruje się właśnie wokół opozycji prawdy i fikcji. Reportaż to dla piszacej przede wszystkim tekst o zdarzeniach mających wartość historyczną. W tym upatruje Krall zarówno wielką siłę, jak i jednocześnie dużą słabość tego gatunku. Zwraca uwagę, że czytelnicy w literaturze faktu nie poszu- 
kują głębszych znaczeń ani ponadczasowych prawd. Przedstawiane historie mają dla nich bowiem charakter ,jednorazowy”53. Reportaż literacki - jak się zdaje aspiruje do tego, by pokazać pewne prawdy w ujęciu uniwersalnym i szerzej spojrzeć na wydarzenia opisywane najczęściej przez pryzmat doświadczeń jednostki.

„Po co mi fikcja, jeśli prawdziwe życie jest ciekawsze?”54 - pytała Krall, mając zarazem świadomość, iż prezentowane przez nią podejście, zakładające hermetyczność granic między obiema formami, to tylko jeden $z$ wariantów, spośród których wybierają dziś autorzy zainteresowani non-fiction:

reportaż jest coraz bardziej zachłanny i wchodzi w rewiry zastrzeżone dotychczas dla literatury pięknej. Okazuje się, że o mrocznych sekretach duszy można pisać również reportaże. Nie wyobrażałam sobie nigdy, że można pisać o tym, o czym piszą Wojtek Tochman czy Mariusz Szczygieł. Oni poszerzają granice gatunku ${ }^{55}$.

Warto podkreślić, że wspomniane przez dziennikarkę poszerzanie granic gatunkowych było też tematem analizowanym przez Wańkowicza. Dla Krall proces ten łączy się głównie $z$ pogłębioną introspekcją i powolnym przechodzeniem reportażu od zdarzeń do emocji, co znacząco zbliża go do literatury. Zdaniem autora Tworzywa, wiązał się z kolei $z$ wykorzystywaniem przez piszących wyobraźni.

Wbrew deklaratywnym zapewnieniom dziennikarki o jej całkowitym odejściu od literatury w stronę dziennikarstwa, badacze zwracają uwagę na niezwykle silny w jej twórczości pierwiastek literackości. W taki sposób analizowana bywa chociażby Sublokatorka, w której Iwona Mandziej doszukuje się zarówno elementów literackich, jak i reportażowych ${ }^{56}$. Zdaniem badaczki, owa książka jest trudna do jednoznacznego zaklasyfikowania i cechuje ja swoista hybrydyczność formalna. Krall wykorzystała w niej bowiem rozmaite techniki powieściowe, opowiadając przy tym historię opartą w dużym stopniu na wydarzeniach autentycznych. Według Wiesława Kota dziennikarce udało się wykroczyć poza formułę prasowego reportażu i nadać książce cechy charakterystyczne dla literatury ${ }^{57}$. Warto odnotować, że metoda twórcza zastosowana w Sublokatorce w 1985 roku bywa wykorzystywana także współcześnie - przywołajmy tylko głośną Córeńkę Tochmana, łączącą w sobie elementy mikropowieści oraz reportażu literackiego.

Krall wielokrotnie jako swój dziennikarski autorytet wskazywała Kapuścińskiego. Doceniała zwłaszcza kunszt jego tekstów i ogromną dociekliwość motywująca go do wyruszania w kolejne podróże. Równocześnie przypominała czytelnikom jedną podstawową cechę, która w sposób zasadniczy odróżniała jej prace od książek autora Cesarza:

Trzeba mieć wielką odwagę i wielką siłę, by, jak Kapuściński, zmierzyć się z całym światem. Nie mam w sobie takiej odwagi i takiej wiedzy. Wszystko sprowadzam do pojedynczego człowieka, bo tego jednego mogę ogarnąć, pojać, kiedy trzeba - zmierzyć się z nimº

Ibidem, s. 51.

Ibidem, s. 34 .

Ibidem, s. 52-53.

I. Mandzi ej, Między reportażem a mikropowieścia. O „Sublokatorce” Hanny Krall. „Pamiętnik Literacki” 1998, z. 3, s. 86.

W. Kot, Hanna Krall. Poznań 2000, s. 52.

Reporterka, s. 46. 
Wydaje się, że przedstawiciele młodej polskiej szkoły reportażu, próbując zdefiniować cel i charakter swej twórczości, wybierają zazwyczaj jedna z dwóch wskazanych przez dziennikarkę dróg. Pierwsza $z$ nich, która podążają m.in. Tochman czy Szczygieł, jest drogą Krall, skoncentrowanej na opowiadaniu o wydarzeniu przez pryzmat jednostki. Druga - bliska Wojciechowi Jagielskiemu - to droga przetarta przez Kapuścińskiego, starającego się spojrzeć na opisywane wydarzenia w sposób panoramiczny i wieloaspektowy.

Badacze twórczości Kapuścińskiego często stawali przed dylematem, w jaki sposób zaklasyfikować teksty tego autora. Beata Nowacka odnotowuje, że w literaturze przedmiotu posługiwano się już takimi określeniami, jak reportaż paraboliczny, reportaż-esej, reportaż-impresja czy reportaż psychologizujący ${ }^{59}$. Literackość i artyzm tekstów Kapuścińskiego wprowadzały początkowo w ogromne zakłopotanie teoretyków przywiązanych do ściśle wyznaczonych ram gatunkowych. Już w 1964 roku Henryk Bereza pisał w „Roczniku Literackim”, że młody reporter stosuje w swych tekstach „chwyty narracyjne i stylistyczne prozy artystycznej” 60 . Wolny-Zmorzyński zauważa $z$ kolei, iż twórczość tego autora „podąża w stronę łączenia wielu technik pisarskich, tworzac collage utkany z przekazów publicystycznych i literackich [...]"61.

Ramy uprawianego przez siebie gatunku próbował wyznaczyć także sam Kapuściński. Jego wypowiedzi teoretyczne najczęściej ogniskowały się wokół założeń reportażu literackiego. W odróżnieniu od Wańkowicza i Krall, Kapuściński w definiowaniu tej formy kładzie nacisk zwłaszcza na jej swoista polifoniczność. Szczególną wagę przywiązuje do kwestii autorstwa, które tylko pozornie jest precyzyjnie określone:

Gatunkiem, który staram się uprawiać, jest literacki reportaż oparty na doświadczeniach wieloletnich podróży po świecie. Każdy reportaż ma wielu autorów i tylko dawno przyjęty zwyczaj powoduje, że tekst podpisujemy jednym nazwiskiem. W rzeczywistości jest to - być może - najbardziej zbiorowo, kolektywnie tworzony gatunek literacki, jako że w jego powstaniu uczestniczą dziesiątki ludzi - naszych rozmówców spotykanych na drogach świata $[\ldots]^{62}$.

Literackość stanowi dla Kapuścińskiego sposób na przedstawienie nierzadko skomplikowanej sytuacji Innego, na opowiedzenie o nim przy użyciu parabol i odniesień znanych już polskiemu czytelnikowi. Literackość to poszukiwanie formy, tworzenie spójnej narracji, która przyciagnie uwagę czytelnika.

Ewa Chylak-Wińska podkreśla charakterystyczną metodę definiowania przez Kapuścińskiego pojęcia faktu. Twórca Cesarza zdecydowanie odchodzi od sposobu, w jaki to pojęcie rozumieja politycy czy historycy. Zdaniem badaczki, „Kapuściński uznaje za fakt kontekst, atmosferę, klimat, nastrój, zapachy, dźwięki, barwy, emocje danego człowieka czy społeczeństwa, i do opisania tych imponderabiliów potrzebuje narzędzi literackich"63. To zatem prowadzona narracja w pewnym sensie s. 7 .

60 H. B e r e za, Powieść, opowiadanie, reportaż. „Rocznik Literacki” 1964, s. 102.

61 K. Wolny-Zmorzyński, Ryszard Kapuściński w labiryncie wspótczesności. Kraków 2004, s. 196.

Ka pu ś c iń s ki, Ten Inny. Kraków 2006, s. 9

E. Chylak-Wiń ska, Afryka Kapuścińskiego. Poznań 2007, s. 152. 
narzuca autorowi dobór środków, które wydają się najbardziej adekwatne do opisu rzeczywistości. Literackość jest tutaj nie tyle jedną z technik mówienia o świecie, ile raczej jedynym możliwym sposobem opowiedzenia o sytuacji Innego; narzędziem wykorzystywanym przez dziennikarza, który - zdaniem Kapuścińskiego - ma przede wszystkim pełnić funkcję tłumacza kultur.

Literackość to bez wątpienia jeden z centralnych elementów refleksji medioznawczej najwybitniejszych polskich reporterów, uważanych za ojców i głównych teoretyków tego gatunku. Jednak zacieśniające się więzy między reportażem a literaturą dostrzec można również wśród przedstawicieli młodszej generacji twórców. Warto sięgnąć chociażby po ostatnią książkę Szczygła, Projekt: prawda, w której dziennikarz - obok własnych tekstów - przedrukował w całości krótką powieść Stanisława Stanucha Portret z pamięci64 ${ }^{64}$. Tekst dziennikarski i beletrystyka połączone zostały przez reportera wspólnym, niezwykle sugestywnym hasłem: prawda. Dzięki zastosowanemu zabiegowi udało się Szczygłowi pokazać, że wzrastająca dziś popularność reportażu literackiego jest w dużej mierze odpowiedzią na zmieniające się oczekiwania czytelników, łączących swe zainteresowanie bieżącymi wydarzeniami $z$ nastawieniem na spotkanie z zajmujacym, precyzyjnie skonstruowanym tekstem.

Rozwijające się dziś tzw. nowe dziennikarstwo (ang. New Journalism) każe reporterom zwrócić się w kierunku technik artystycznych i odrzucić bądź przynajmniej podać w wątpliwość sens tworzenia holistycznych narracji, naśladujących styl XIX-wiecznej noweli. Dla piszących ważne stają się teraz nawiązania intertekstualne, retrospekcje, dialogiczność tekstu, a nawet mediatyzacja, które zdecydowanie lepiej zdają się ukazywać współczesny szum informacyjny niż hermetyczne informacyjne gatunki dziennikarskie ${ }^{65}$. Zarówno geneza, jak i przyszłość reportażu literackiego bardzo silnie uwikłane są zatem w konteksty literackie, dla jednych autorów stanowiące źródło inspiracji, dla innych z kolei punkt wyjścia do dyskusji nad granicami gatunku.

Abstract

EDYTA ŻYREK-HORODYSKA Jagiellonian University, Cracow

\section{A LITERARY REPORT AGAINST LITERATURE ROOTS AND THEORIES}

The present sketch is aimed at an analysis of the relations between a literary report and literature. In establishing those connections it is vital to pay attention both to the diachronic changes showing the way a report and its producers over a span of centuries became independent from literature, as well as to the changes in the genre's poetics. A likewise important element of the analyses in question is a focus on the autothematic statements by the writers themselves (such as Melchior Wańkowicz, Hanna Krall, and Ryszard Kapuściński) who, reflecting on the frames of the genre, many a time touched the issues connected with journalistic and artistic forms interaction. jest na białym papierze, tekst Stanucha z kolei na żółtych kartkach. Dzieło literackie zostało więc włączone do dziennikarskiego, ale przy zachowaniu pewnej odrębności. 